\title{
RECIPROCAL QUESTIONING PROCEDURES IN READING COMPREHENSION: DOES IT INCREASE STUDENTS' MOTIVATION?
}

\author{
${ }^{\# 1}$ Bq Zuhrotun Nafisah, ${ }^{* 2}$ Dedi Sumarsono
}

${ }^{\# 1}$ English Lecturer, FBMB, Universitas Pendidikan Mandalika, Indonesia

${ }^{* 2}$ English Lecturer, FBMB, Universitas Pendidikan Mandalika, Indonesia

Corresponding Author Email: baiqzuhrotunnafisah@undikma.ac.id

\section{A B S T R A C T S}

Reading is essential and serves as a basic building block in English language learning process. As a result, a teacher must have an effective teaching technique in teaching reading comprehension. This study aims to find out the influence of reciprocal questioning towards students' motivation in reading comprehension of the third-grade students at SMP Negeri 3 Praya. The research was conducted through experimental research, the pre-test and post-test were used as the design. The instrument was used a set of questionnaires (Likert scale) for motivation test. The data analysis that used was descriptive analysis and inferential analysis for measuring the motivation test in form of questionnaires. Then, according to the result of the test, it showed that t-test 4.865 was higher than the t-table 2.423 at the level of significance 0.50 . It means that, there was a positive effect of Reciprocal Questioning procedure towards students' motivation in reading comprehension.

\begin{tabular}{l}
\hline A R T I C L E I N F O \\
\hline Article History: \\
Received: November, 2021
\end{tabular}

Revised: December, 2021

Published: December, 2021

Keywords:

Reciprocal Questioning

Procedure,

Motivation,

Reading Comprehension

How to cite: Nafisah, B., \& Sumarsono, D. (2021). Reciprocal Questioning Procedures in Reading Comprehension: Does It Increase Students' Motivation?. Jo-ELT (Journal of English Language Teaching) Fakultas Pendidikan Bahasa \& Seni Prodi Pendidikan Bahasa Inggris IKIP, 8(2), $163-171$. doi:https://doi.org/10.33394/jo-elt.v8i2.4423

\section{INTRODUCTION}

One of the essential skills in English is reading. Reading regards as a receptive skill in comprehending words in written form. Nunan (1991) stated that reading is an activity in which the aspects outside the text interacted with the elements of the text where the prior knowledge that the readers have about the texts' substance is particularly important. It means that, the students have to be able to comprehend and acquire the message that was conveyed by the writer instead of only focusing on reading the text.

The ability of students in reading provides students with several benefits. The first one is, students will be able to learn new things certainly about what the text is about. The second is, after participating in reading activities, they will be able to acquire new vocabulary. And the last, the structure of English language will be able to be learned by them. Therefore, reading is the ability that takes up the most time in high school English classes. By obtaining those benefits, the students can not only improve their reading comprehension, but also their English skill.

Reading comprehension was emphasized by the majority of Indonesian schools' curriculum. Various kind of English texts was expected to acquire by the students of Junior High school. It means that, in the process of teaching and learning, a variety of material will 
be encountered by the students. Most teachers used exactly the same teaching method in reading comprehension, the teachers targeted the students on some objectives such are what the main idea of the text is what they should be able to find out, as well as finding difficult terms, determining words' meaning and sentences' meaning. However, the students' ability to comprehend the reading text is still average although they spend their time conducting the reading activities in the class. It indicates that they are having severe difficulties in conducting the reading activity in the classroom. That is why, they need to enhance their capacity to absorb information from various kinds of texts.

Based on the researcher's observation at the third grade on SMPN 3 Praya on the implementation of the teaching and learning process of reading comprehension class, the teacher only used one technique in teaching reading comprehension and having the students read the texts or story on the book, without giving explanation more clearly about the text and instructing the students to respond to the questions based on the text that they read, this suggests the teacher was unable to push them to acquire new concepts and was unably generating them to be more active, productive and creative in the classroom because the teaching technique was tedious.

From the elaborated-problem in the previous paragraph, it is clear that the issues stem is from an ineffective learning technique and environment. As a result, the teachers must develop better learning techniques that lead the students to be engaged in English class while also encouraging them to improve their reading comprehension. Therefore, the researcher proposed a learning strategy to inscrease the motivation of students in reading. It can be seen that the teaching strategy offered by the teacher affected the students in the classroom, and the researcher expect that the strategy that will be proposed helped the students to get a better achievement and lifting up their motivation in their learning. One of the strategies is "Reciprocal Questioning Procedure".

According to Manzo (1969) in Crawford et al (2005: 69) "Reciprocal Questioning Procedure is a useful activity partners can use when they are reading through a text that is difficult for them". It means that, Reciprocal Questioning Procedures can be a beneficial activity for the students when they find it difficult in comprehending the text in reading comprehension class. So, the students changed the information and ask each other about the problems of the text that the students believed was difficult. This strategy helped the students comprehending the meaning of the text. Hamilton, in Ersianawati (2018:20) explains that Reciprocal Questioning strategy is engaged the students actively in reading the text through questions.

According to Hales (2009) in Ersianawati (2018:20), Reciprocal Questioning technique helps the students learn to create effective questions. The students learn to develop their own questions about the text so the students can comprehend the text independently. Since questioning is known can make the readers find their own way to comprehend the text. In short, the Reciprocal Questioning technique involves both the teacher and the students in the creation and response of questions, allowing students to actively participate in the text through questions. This technique also can help the students create effective questions about the text that they are reading. As stated by Foster and Rotoloni in Fahas (2021:38) define Reciprocal Questioning provides students with a model and sharpens their cognitive process on how to convey what they have learned. In addition, Brown (2000) said that Reciprocal teaching is based on Vygotsky's theory of ZPD (Zone of Proximal Development) which focuses on class interaction in increasing students' knowledge and skills. Dornyei (2001) stated that the students who have a desire to learn are more likely to succeed. Motivation is the term used to describe this.

Motivation takes an important role in EFL students' performance in the classroom. As stated by Chowdhury, et al. (2021) that there is a connection between students' achievement 
and their motivation. The individual internals' process initiates, leads and maintains their behavior in trying to reach the learning objectives. (Kurt \& Kecik, 2017) said that one of the most essential aspects influencing students' English performance is motivation. Baron and Donn, in Bakar (2014) stated that motivation improves the quality of student's performance by encouraging them to be more diligent, interested, and disciplined. Those characteristics that were stated could be seen in the process of teaching and learning, some students that have a care on what they learn, have the ambition to do more, engaged in learning, constantly aim for the best achievement, and obey the rules is possible to say that the students have motivation.

Muslim, et al. (2020) in their research categorized the learning motivation into various types generally. When the students enjoy the process of teaching and learning, they demonstrate instrumental motivation. The two main categories of motivation are intrinsic and extrinsic. The intrinsic motivation is referred to as a desire for something that comes from the individual behaviour (Oletić \& Ilić, 2014). On the other hand, extrinsic motivation is a desire to something because the individual is expecting to earn rewards, so the factor comes outside the individual itself such as a good mark, honor, gift, etc. Intrinsic motivation can be either integrative or instrumental (Gardner, 2010). Both types of intrinsic motivation have a positive influence on learning English as a foreign language $(\mathrm{Ng} \& \mathrm{Ng}, 2015)$. Pecjak and Kosir; (2008), Mubarok and Sofiana (2017) stated that motivation in reading comprehension encourages students to associate their reading behavior with each other to reach the goals. It implies that the students who are highly motivated would read more efficiently.

\section{RESEARCH METHOD \\ Research Design}

The researcher employed a quantitative approach. Quantitative research was an approach for testing objective theories by examining the relationship among variables. This research used experimental research. The researcher used true - experimental research design, which means the population of this research is more than two classes, and the researcher used an experimental group and control group. The researcher used prequestionnaire and post-questionnaire designs. In this research, a pre-questionnaire was used before giving treatment and a post-questionnaire after it.

\section{Population and Sample}

The population of this research is the third-grade students of SMPN 3 Praya. The total number of students was 125 students, which consist of five classes. The researcher then used simple random sampling to choose which class as the experimental group and the control group. The researcher took two classes and each class consists of 25 students. It means that the total sample is 50 students.

\section{Instruments}

The instruments were based on the indicators of motivation and the instrument was based on material thought or called content validity after that it was consulted to the experts as it was called face validity. The data was collected from all information directly gather from the samples. The researcher got the data from pre-questionnaires and post-questionnaires. The type of questionnaire is closed-ended questionnaire. The aim of the pre-questionnaire is to know students' motivation in reading comprehension before giving a treatment. Both of experimental and control groups have the same type of questionnaire that is in checklist items which consist of 20 questions. After that, the researcher gave a post-questionnaire. The postquestionnaire is aimed to know the effect after the researcher gives treatment to the experimental group. The researcher gave a post-questionnaire in checklist items which 
consist of 20 questions. The purpose of using questionnaire here is to know students' motivation in reading comprehension after giving a treatment.

\section{Data Analysis}

The data in this research was analyzed by applying descriptive statistics and inferential statistics. The descriptive statistics consisted of the basic feature of the data which are mean, mode and median. In inferential statistics, the data were analyzed by using a t-test. The sample t-test was used for comparing the score of the two groups. The researcher compared the result of the t-test to the t-table to find out whether the Reciprocal Questioning Procedure has positive effect towards students' motivation in reading comprehension. However, before analyzing the data using a t-test, the researcher analyzed the validity and reliability of the data which were collected through the instrument using Cronbrach's method.

\section{RESEARCH FINDINGS AND DISCUSSION Research Findings}

Base on the data analysis, the experimental group's highest score of pre-test was 79, and the lowest score was 20 and the mean of pre-test was 46.56, the mode score was 27.7 the median score was 25.5 and the standard deviation was 1.704 . The following data frequency of distribution was generated using data analysis techniques.

Table 1

Descriptive Analysis pre-test of Experimental Group

\begin{tabular}{|ll|r|}
\hline $\mathrm{N}$ & Valid & 25 \\
& Missing & 0 \\
Mean & & 46.56 \\
Median & & 25.5 \\
Mode & & 27.7 \\
Std. Deviation & & 1.704 \\
Range & & 18 \\
Minimum & & 20 \\
Maximum & & 79 \\
\hline
\end{tabular}

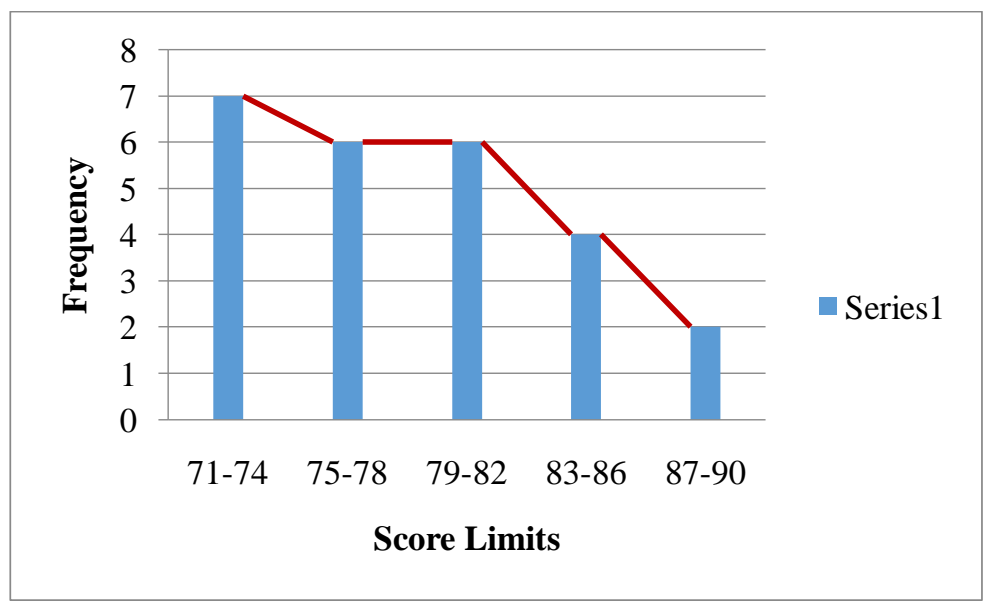

Figure 1. Histogram and Polygon of Pre-Test in Experimental Group

The data analysis showed that the highest score of post-test in the experimental group was 89 , the lowest score was 73 and the mean of post-test was 81.36 , the mode score was 82 
the median score was 82.6 and the standard deviation was 2.940. The following data frequency of distribution was created based on steps of data analysis.

Table 2.

Descriptive Analysis post-test of Experimental Group

\begin{tabular}{|lr|r|}
\hline $\mathrm{N}$ & Valid & 25 \\
& Missing & 0 \\
Mean & & 81.36 \\
Median & & 82.6 \\
Mode & & 82 \\
Std. & & \\
Deviation & & 2.940 \\
Range & & 16 \\
Minimum & & 73 \\
Maximum & & 89 \\
\hline
\end{tabular}

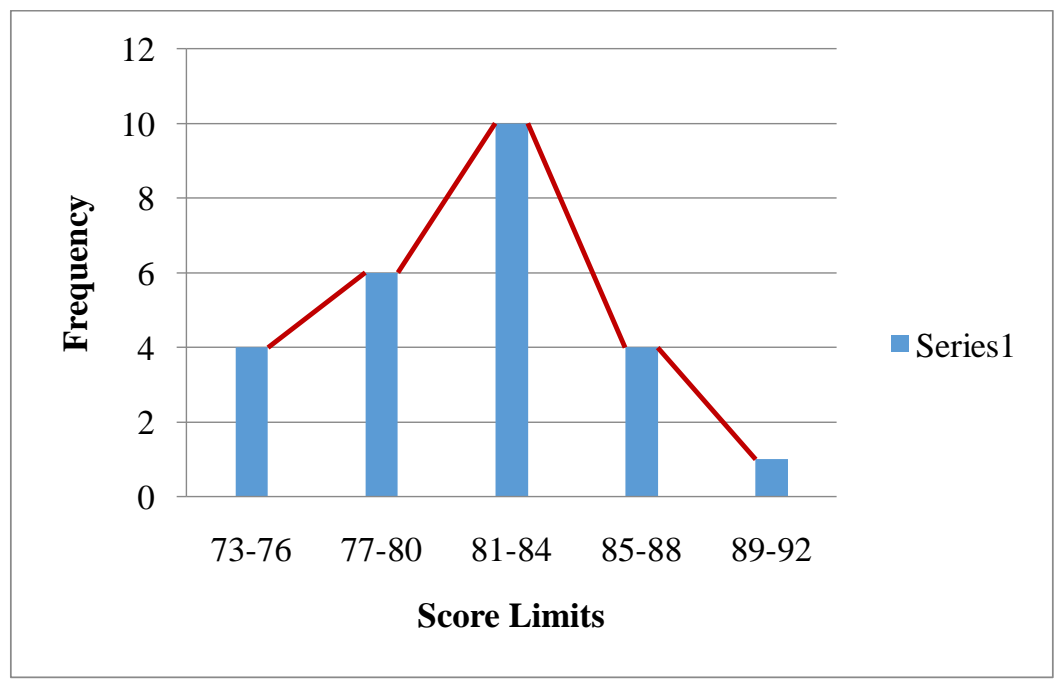

Figure 2. Histogram and Polygon of Post-Test in Experimental Group

From the histogram and polygon above, it can be seen that the frequency of students who got score between 73-76 was 4 students. The frequency of students who got score between 77-80 was 6 students. Then the frequency of students who got score between 81-84 was 10 students. The frequency of students who got score between 85-88 was 4 students and the last that the frequency of students who got 89-92 was only 1 student. At the end, the hypothesis was tested by using the t-test formula. It shows that t-test was 4.865 and the t-table was 2.423 at the significance level of 0.05 with the degree of freedom 48 . Based on the data, it is obtained that the criteria value of the t-test is higher than the t-table $(4.865>2.423)$, which can be concluded that the Reciprocal Questioning Procedure increased students' motivation in reading comprehension.

\section{Discussion}

Reciprocal Questioning Procedure has positive effect towards students' motivation in reading comprehension. As a result of the analysis data in findings that the mean of the experimental group's score is higher than the mean of the control group. Crawford (2005: 69) advocated that Reciprocal Questioning Procedure is a technique which more effortless, straightforward and effective for the teacher to teach reading than the other techniques. It 
means that Reciprocal Questioning Procedure as a teaching technique in the experimental group is better than the teaching method in control group.

Reciprocal Questioning Procedure is one of strategy in cooperative learning. The students have partner to solve the problem in a small group, that is why the students are more active in the classroom. According to $\mathrm{Li}$ and Lam (2013: 01) Cooperative learning emphasizes the students as the centered in the learning activity and focuses on the teacher's instruction that will be delivered to them where they have to be worked together as a group to solve the task and accomplish the learning objectives. On other hands, cooperative learning demands students' ability to improve the way they think, their emotions, and they socialize with each other way, and as a result, it is a good strategy to deal with the issue of individual differences.

In the terms of the students' understanding of how to implement the Reciprocal Questioning Procedure, it has never been taught to them before. The meetings were held twice by the researcher. In the first treatment, the researcher taught "Narrative text: The Donkey of Guizhou". As the first step, the students were instructed to look for four or five of their classmates and make a small group. They were then given a text and instructed to read it and attempt to comprehend it. After that, they had done a group discussion to formulate a list of five questions regarding the text they have read. Furthermore, the students were permitted to consult if they had difficulty in formulating the five questions that were instructed before. After completing their task, each group designated a representative from their group members who were responsible for delivering the questions posed by their group in front of the class. They completed the task by answering the questions correctly, while the other members of the group had difficulty understanding the Reciprocal Questioning Procedure, structuring sentences, formulating questions, and comprehending vocabulary. Even though several groups had difficulty understanding the Reciprocal Questioning method in the first treatment, they loved and became interested in the process.

In the second treatment, the researcher taught "Narrative text: The Rats and the Elephant". In this stage, the steps are similar into the previous one or in the first treatment. The majority of the groups were excited about working together. They assisted each other in groups who were having difficulty understanding the Reciprocal Questioning Procedure, structuring sentences, formulating questions, and comprehending vocabulary. Furthermore, the majority of students became active and got involved in the learning process, and the activity proceeded smoothly because they were previously familiar with the task. At last, most groups completed the task accurately and systematically, despite some grammatical faults in the arrangement and construction of sentences, and they made significant progress in comprehending the text. The purpose of implementing the Reciprocal Questioning technique in teaching reading comprehension is not to determine the best student, but to provide a different way for students to understand the material thoroughly.

This study aimed to figure out the students' motivation in reading comprehension through Reciprocal Questioning Procedure. The data was collected by using twenty item questionnaires. The majority of the students thought this Reciprocal Questioning Procedure was fascinating to be employed in the classroom, and they thought the four stages in Reciprocal Questioning Procedure which are predicting, clarifying, summarizing, and questioning was helpful in helping students to comprehend the material of the text. This technique helps students to have motivation in comprehending the text. Sahab (2014: 87), in his research, Reciprocal Questions Procedure, according to numerous students, the motivation was increased when participating in the discussion. Their anxiety was reduced in the situation of group discussion because they had to deal with only a few classmates in a group. Freihat (2012) also stated that in the group discussion, the anxious students were more inclined to speak up. As in line with Ikhwan, E. J. Q., \& Andriyanti, E (2021) The students' 
motivation is accompanied by effort, activity, persistence, and material attention. Motivation is an essential factor supporting the students' persistence in achieving learning goals. Students' engagement and self-investment in learning activities are depends on motivation. MacIntyre et al. (2001) stated that, motivation is an attribute that describes the qualities that drive a person towards the accomplishment of a particular task both mentally and emotionally. This shown in the process of teaching and learning where the majority of them become more diligent, they were curious and they were not easy to satisfy to what they have reached in the teaching and learning process, they were also active in doing the instruction from the teacher and they were always trying to get the result they expected for. The students are more attracted to the teaching and learning process by using Reciprocal Questioning Procedure. That is why Reciprocal Questioning Procedure can motivate the students to study. According to Vero and Puka (2017: 58) motivation is probably the most important factor that teacher can implement to improve learning. Besides that Kagan (2009) stated, the increase of students' motivation depends on how the task was made to be more engaging and compatible, and this method was preferred to push students to accomplish pointless or uninteresting tasks with extrinsic rewards.

From the previous explanation, it implies that the students were motivated in implementing the Reciprocal Questioning Procedures in the learning process. Because the students have a partner in asking and answering the questions that is why the students are more interactive in the process of teaching and learning. In this case, Reciprocal Questioning Procedure has positive effect towards students' motivation in reading comprehension. Alternative Hypothesis (Ha) which reads" There is positive effect of Reciprocal Questioning Procedure towards students' motivation in reading comprehension at the third-grade student of SMPN 3 Praya in academic years 2017/2018" is clearly accepted, and Null Hypothesis (Ho) is rejected. This statement was supported by the research article of Syaiful \& Ahmad (2016: 70) stated that "Reciprocal technique gives the effect to students motivation". The Reciprocal Questioning technique had a higher chance of engaging students and allowing them to learn in their chosen way. A proportional increase in each student's chances of being actively involved in language use, as well as a broader diversity of language that can be employed by the students.

Besides, Susanti (2013) in her research said that Reciprocal-Questioning (ReQuest) Procedure is a better technique to teach than to teach using traditional strategy. In this case, the experimental group received treatment utilizing the Reciprocal-Questioning (ReQuest) Procedure, while the control group received treatment using the traditional strategy. The Reciprocal-Questioning Procedure is used to teach reading comprehension, which is classified as a good level. The value of the t-table has been consulted in the computations of correlation between two mean deviation scores of the groups. However, before consulting it, the researcher must first decide the significance level and degree of freedom employed in this study. The result of the study is supported by the previous result by Hariyanto, et al (2019) that motivation has high correlation to what students achieved in the learning process.

\section{CONCLUSION}

Based on the findings and discussion, it can be concluded that the Reciprocal Questioning (ReQuest) Procedure can be applied by the English teachers as one of the effective techniques to teach reading comprehension because this technique is intended to provide a different way for the students and to increase students' motivation in comprehending the text. The four stages of Reciprocal Questioning Procedure were helpful as they made the students' progress on their behaviour and performance. As a result, the students are more attracted to the teaching and learning process since the Reciprocal Questioning Procedure motivated the students to study. Furthermore, the achievement of 
students' reading comprehension was improved, which can be seen from the fact that the mean post-test score was higher than the pre-test score. Moreover, the Reciprocal Questioning technique was able to actively engage students with the material, so that the reading activity will be considered as an interesting, engaging, and attracting activity by the students.

\section{REFERENCES}

Bakar, R. (2014). The Effect of Learning Motivation on Student's Productive Competencies in Vocational High School, West Sumatra. International Journal of Asian Social Science, 4(6), 722-732.

Brown, H. D. (2000). Teaching by Principles: An Interactive Approach to Language Pedagogy. San Francisco: Longman.

Chowdury, T., et al. (2021). Learner Motivation in the EFL Classrooms: Voices from a Bangladeshi University. Indonesian Journal of Applied Linguistics, 11(1), 221-232. https://doi.org/10.17509/ijal.v11i1.34618

Crawford, et al. (2005). Teaching and Learning Strategies for the Thinking Classroom. USA: The International Debate Education Association.

Dornyei, Z. (2001). Motivational Strategies in the Language Classroom. Cambridge: Cambridge University Press. http://dx.doi.org/10.1017/CBO9780511667343

Ersianawati, S., \& Suprianti, G.A.P. (2018). Incorporating Reciprocal Questioning Strategy and Numbered Heads Together in Reading Class. International Journal of Language and Literature, 2(1), 19-29. DOI: http://dx.doi.org/10.23887/ijll.v2i1.16090

Fahas, R. (2021). Improving Students' Reading Comprehension Through Request (Reciprocal Question) Strategy for Indonesian Junior High School. SALEE: Study of Applied Linguistics and English Education. 2(1), 37-50. DOI: 10.35961/salee.v2i01.217.

Freihat, S., \& Al-Makhzoomi, K. (2012). The Effect of the Reciprocal Teaching Procedure (RTP) on Enhancing EFL Students' Reading Comprehension Behavior in a University Setting. Jordan: International Journal of Humanities and Social Science, 2(5), 279291.

Gardner, R. (2010). Motivation and Second Language Acquisition: The Socio-Educational Model. New York: Peter Lang Publishing.

Hariyanto., Joyoatmojo, S., Nurkamto, J., \& Gunarhadi. (2019). Correlation of Learning Motivation Based on ARCS Model with English Achievement of Midwifery Students. Lingua Cultura, 13(3), 161-166. https://doi.org/10.21512/lc.v13i3.5571

Ikhwan, E. J. Q., \& Andriyanti, E. (2021). Students' Motivation to Acquire English through Virtual Learning midst Covid-19 Pandemic. Lingua Cultura, 15(1), 11-20. https://doi.org/10.21512/lc.v15i1.6839

Kagan, S., \& Kagan, M. (2009). Kagan Cooperative Learning. San Clemente: Kagan Publishing.

Kurt, P. Y., \& Kecik, I. (2017). The Effects of ARCS Motivational Model on Student Motivation to Learn English. European Journal of Foreign Language Teaching, 2(1), 22-44. https://doi.org/10.5281/zenodo.254605

Li, M. P., \& Lam, B. H. (2013). Cooperative Learning. Hongkong: The Hong Kong Institute of Education.

MacIntyre, P. D., K, M., \& Baker, S. C. (2001). The Convergence of Multiple Models of Motivation for Second Language Learning: Gardner, Pintrich, Kuhl, and McCroskey. in Z. Dornyei \& R. Schmidt (Eds.), Motivation and Second Language Acquisition (Technical Report 23) (pp. 461-492). Honolulu: University of Hawai, Second Language Teaching and Curriculum Center. 
Mubarok, H., \& Sofiana, N. (2017). Cooperative Integrated Reading and Composition (CIRC) and Reading Motivation: Examining the Effect on Students' Reading Ability. Lingua Cultura, 11(2), 121-126. http://dx.doi.org/10.21512/lc.v11i2.1824

Muslim, A. B., Hamied, F. A., \& Sukyadi, D. (2020). Integrative and Instrumental but Low Investment: the English Learning Motivation of Indonesian Senior Secondary School Students. Indonesian Journal of Applied Linguistics, 9, 493-507. DOI: 10.17509/ijal.v9i3.23199.

Ng, C., \& Poh Kiat Ng. (2015). A Review of Intrinsic and Extrinsic Motivation of ESL Learners. International Journal of Language, Literature and Linguistics, 1(2), 98-105. DOI: 10.7763/IJLLL.2015.V1.20.

Nunan, D. (1991). Language Teaching Methodology: A Textbook for Teacher. Upper Saddle River, NJ: Prentice Hall.

Oletić, A., \& Nina, I. (2014). Intrinsic and Extrinsic Motivation for Learning English as a Foreign Language. ELTA Journal, 2(2), 23-38.

Sahab, R. (2014). The Use of Reciprocal Teaching Procedure in Teaching Narrative Texts to Improve Students' Reading Comprehension. Journal of English and Education, 2(2), 81-90.

Susanti, E. (2013). The Effect of Using Request Procedure towards Reading Comprehension of the Second Year Students at MA Diniyah Puteri. Skripsi. Thesis, Universitas Islam Negeri Sultan Syarif Kasim Riau.

Syaiful \& Zulpahmi, A. 2016. The Effect of Reciprocal Teaching Strategy Toward Students' Motivation and Their Reading Ability at Senior High School in Rambah Hilir District Rokan Hulu Regency. Journal of English Education, 3(2), 62-72.

Vero, E., \& Puka, E. (2017). The Importance of Motivation in an Educational Environment. Formazione \& Insegnamento, XV(1), 57-66. doi:107346/- fei-XV-01-17_05. 